\title{
PERGESERAN GENDER PADA INTERIOR RUMAH TINGGAL DI KAWASAN JERON BENTENG YOGTAKARTA
}

Martino Dwi Nugroho* Program Studi Desain Interior, Fakultas Seni Rupa, Institut Seni Indonesia Yogyakarta

One of the instruments incorporated for the construction of social reality is gender. Javanese society traditionally embraces social concept of patriarchy. The general Implication is that woman becomes a man's subordinate. Broader implementation also can be comprehended from dissociation of social activities and rituals involving both men and women. Viewed from the spatial perspective, there are differences between man space and woman space. This is based on the research conducted in Jeron Beteng, an area in the city of Yogyakarta. The analysis has resulted what follows: (1) the sittingroom shows a friction; once mastered by man now it turns into equation with indicators : equal status ownership, custom affection, domestic duty execution, and sittingroom domination; influencing factors :modernization, attitude and emancipation respect. (2) the livingroom also demonstrates a friction; once a woman domain, today it is accessible to man as well; influencing factors: communication, marital status, age, work, emancipation, modernization, moral and formal education, and foreign culture, (3) the kitchen witnesses an equal role for a woman and man regarding domestic duty, openness and communication. Woman, however, remains to be more dominant in kitchen although men have access in there; influencing factors: communications, age, work, emancipation, modernization, moral and formal education.

\section{Keywords: gender, interior, sitting room, livingroom, kitchen}

Pembicaraan tentang ruang tidak bisa lepas dari segi arsitekturalnya. Konteks ruang di sini berkaitan dengan rumah, yang disebut omah/papan oleh masyarakat Jawa. Pemahaman tentang rumah sama dengan pemahaman mengenai kehidupan suatu kelompok kebudayaan yang sering memancarkan suatu watak khas tertentu yang tampak dari luar. Rumah dalam kaitan ini merupakan suatu konsep orang Jawa dalam mengaktualisasikan diri, baik pribadi maupun sosial. Makna rumah lebih dari sekedar struktur bangunan fisik semata. Rumah adalah satuan simbolis, sosial dan praktis.

Dalam pandangan masyarakat Jawa, keseimbangan antara hak dan kewajiban selalu berlangsung dalam ruang, waktu, makna dan pesan. Kebudayaan Jawa memiliki sistem kekerabatan yang unik, yang memperlihatkan kedudukan dan peran seseorang di dalam kehidupan bermasyarakat dan berkeluarga, termasuk di dalamnya memperlihatkan sistem kekerabatan antara pria dan wanita, dimana dalam penelitian ini disebut sebagai relasi gender.

Masyarakat Jawa secara tradisi menganut konsep sosial gender yang patriarkis. Implikasi secara umum adalah wanita menjadi subordinat pria. Oleh karena itu pewaris tahta kerajaan kecenderungannya adalah putera mahkota, bukan puteri.

*Korespondensi penulis dialamatkan ke Program Studi Desain Interior, Fakultas Seni Rupa, Institut Seni Indonesia Yogyakarta, Telp/Fax: +62 274417219 e-mail:tino_di@yahoo.com 
Implementasi lebih luas juga dapat dipahami dari pemisahan kegiatan sosial dan ritual bagi pria dan wanita. Sehingga secara ruang terdapat perbedaan antara ruang bagi lakilaki dan ruang bagi perempuan. Bias gender tak pelak lagi membayangi pembahasan tentang rumah tinggal ketika lelaki dan perempuan berbagi peran di dalam setiap ruangnya.

Secara umum, perbincangan mengenai gender tidak dapat terlepas kaitannya dengan relasi antara pria dan wanita, dimana pada dewasa ini perbincangan tersebut menghangat seiring dengan adanya kesadaran akan terjadinya ketimpangan dalam hubungan dan kedudukan antargender.

Secara historis, relasi gender dalam masyarakat Jawa tersebut juga direpresentasikan melalui ruang arsitektur, dalam hal ini diperlihatkan dalam konsep tata ruang rumah tradisional Jawa pada masa dahulu dimana konsep ruangnya masih dipengaruhi oleh pembatasan gender. Arsitektur sebagai salah satu produk budaya manusia adalah implementasi dari kondisi kultural sosial dan psikologis masyarakat, demikian pula halnya pembagian gender yang terbentuk dari lingkungan sosial dan psikologis masyarakat. Terjadinya pergeseran kedudukan dan relasi gender masyarakat Jawa pada masa sekarang yang disebabkan antara lain oleh modernisasi, emansipasi wanita, dan masuknya pengaruh budaya Barat, telah menggeser pola relasi gender mengarah kepada persamaan derajat dan kedudukan. Pergeseran pola relasi gender tersebut, khususnya yang terjadi dalam keluarga Jawa, secara perlahan telah menggeser konsep gender dalam rumah tinggal.

Sehingga menarik untuk diteliti terutama pada pergeseran konsep gender akibat dari perubahan sosial tersebut dalam interior rumah tinggal terutama pada ruang tamu, ruang keluarga dan dapur, yang mana ruang-ruang tersebut menurut konsep arsitektural Jawa sangat kentara adanya pembatasan menurut gender, sejauh mana pergeseran itu terjadi dan apa latar belakangnya.

Yogyakarta merupakan salah satu kota pewaris tradisi kerajaan Jawa, Mataram dan salah satu pusat kebudayaan Jawa yang sekarang terkena dampak modernitas dalam segala segi kehidupan. Salah satu hasil kebudayaan adalah rumah tinggal. Segala aktifitas dan interaksi pada rumah tinggal terpentaskan dalam ruang-ruang. Konfigurasi ruang dikonsepkan sebagai pengejawantahan dari kekuasaan yang mengaturnya, maka akan selalu ada kewenangan atas setiap ruang yang memiliki aturan. Pemahaman penghuni terhadap makna yang terbentuk di dalam rumahnya akan terwujud sebagai susunan ruang dan tercermin dalam perilaku keseharian dengan mengekspresikan pemahamannya terhadap rumah melalui penyusunan obyek maupun penempatan tubuh dalam ruang. Dalam hubungan antara susunan ruang dan tindakan ragawi, terdapat dua cara utama untuk menyatakan suatu setting ruang secara positif dengan mengartikulasikan pusatnya dan secara negatif dengan mendefinisikan batasnya.

Jeron beteng adalah salah satu kawasan dari Kota Yogyakarta yang menarik untuk diteliti. Istilah Jeron Beteng biasa dipakai untuk menyebut kawasan di bagian dalam benteng yang mengelilingi Keraton Kasultanan Yogyakarta, yang menjadi situs pusaka budaya utama di Kota Jogja. Kawasan ini memiliki pola tata ruang yang khas, bangunan-bangunan bersejarah, serta pola tata nama yang masih lestari sejak pertama kali adanya sejak satu dua abad yang lampau. Kawasan Jeron Beteng dibangun bersamaan dengan perkembangan pembangunan Karaton Ngayogyakarta yang dimulai pada tahun 1755 sebagai inti kota Yogyakarta atas perintah Sri Sultan Hamengku Buwono I untuk membuat perkampungan bagi para abdi dalem yang langsung melayani kerumahtanggaan Kraton. Jeron Beteng termasuk perkampungan pertama sejak Yogyakarta berdiri pada tahun 1765 (Laboratorium Arsitektur FT. UGM, 1970). Sehingga dapat dikatakan bahwa kawasan Jeron Beteng merupakan representasi dari Kota Yogyakarta dari aspek sosial budaya.

Karena letaknya yang berada di sekeliling kraton maka kawasan ini sangat terpengaruh dengan tradisi kraton. Sebagai bagian dari suatu era, kawasan ini secara 
langsung ataupun tidak langsung juga akan terpengaruh oleh modernitas. Sehingga terjadi penyesuaian-penyesuaian terhadap nilai budaya kesehariannya termasuk di dalamnya soal menata dan pemanfaatan ruang pada rumah tinggalnya. Persoalan ini menarik untuk diteliti terutama mengenai bagaimana pergeseran gender terjadi serta faktor-faktor apakah yang menjadi latar belakang perubahan tersebut.

\section{TINJAUAN TENTANG JERON BETENG}

Pada hari Kamis Pon tanggal 3 Sura, Wawu 1681 tahun Jawa, wuku Kuruwelut atau pada tanggal 9 Oktober 1755 Sri Sultan Hamengku Buwono I memerintahkan untuk membangun Karaton Ngayogyakarta Hadiningrat di desa Pacethokan dalam hutan Beringin. Setahun kemudian tepatnya pada hari Kamis Pahing 13 Syura, Jimakir 1682 tahun Jawa, wuku Julungwangi atau tanggal 7 Oktober 1756 Sri Sultan Hamengku Buwono I beserta keluarganya memasuki Karaton Ngayogyakarta Hadiningrat yang baru dan untuk sementara waktu menempati gedhong sedhahan. Peristiwa pindahnya Sri Sultan Hamengku Buwono I dari Ambarketawang ke Karaton Ngayogyakarta Hadiningrat ini ditandai dengan candra sengkala memet Dwi Naga Rasa Tunggal, berupa dua ekor naga yang kedua ekornya saling melilit yang diukirkan di atas banon atau renteng kelir baturana kagungan dalem regol kemagangan dan regol Gadhung Mlathi.

Mulai saat itu berbagai macam sarana dan bangunan pendukung untuk mewadahi aktivitas pemerintahan, baik kegiatan sosial, politik, ekonomi, budaya maupun tempat tinggal mulai dibangun secara bertahap. Pembangunan Karaton Ngayogyakarta Hadiningrat sebagai pusat (centrum) pengembangan Kota Yogyakarta selain memenuhi aspek fungsi juga didasari aspek politis, strategis, teknis dan filosofis religius.

Bersamaan dengan perkembangan pembangunan Karaton Ngayogyakarta Hadiningrat, Sri Sultan Hamengku Buwono I memerintahkan juga untuk membangun kampung-kampung di sekeliling Baluwarti Kraton dimulai dari perkampungan untuk rumah asrama prajurit kraton dan perwiranya, perkampungan para abdi dalem yang langsung melayani kerumahtanggaan kraton, perkampungan untuk para pejabat tinggi negara, perkampungan untuk para ahli teknik kraton dan lain sebagainya. Untuk para prajurit dan Bupati Nayaka berada diluar benteng, sedangkan untuk para abdi dalem tetap berada di dalam kawasan jeron benteng. Mereka menempati kampungkampung yang sesuai dengan tugas yang diembannya, misalnya :

a. Kampung Siliran, ditempati abdi dalem silir yang mempunyai tugas memelihara lampu.

b. Kampung Gamelan, ditempati abdi dalem gamel yang bertugas memelihara kuda-kuda kerajaan.

c. Kampung Patehan, tempat abdi dalem yang mengurus minuman untuk kraton

d. Kampung Langenastran, tempat abdi dalem langenastra selaku pengawal raja.

e. Kampung Kemitbumen, tempat abdi dalem yang mempunyai tugas sebagai pembersih Kraton.

f. Kampung Pesidenan, tempat tinggal abdi dalem pesinden atau wiraswara yaitu mereka yang bertugas untuk menembangkan tembang-tembang Jawa dalam upacara-upacara Kraton.

g. Kampung Nagan, tempat abdi dalem yang bertugas menabuh gamelan.

h. Kampung Suranatan, merupakan tempat tinggal para abdi dalem yang bertugas dalam bidang keagamaan, yaitu sebagai ulama Kraton. 
LINTAS

RUANG | VOL.2 | EDISI 2 | 2008

ISSN 1978-0702
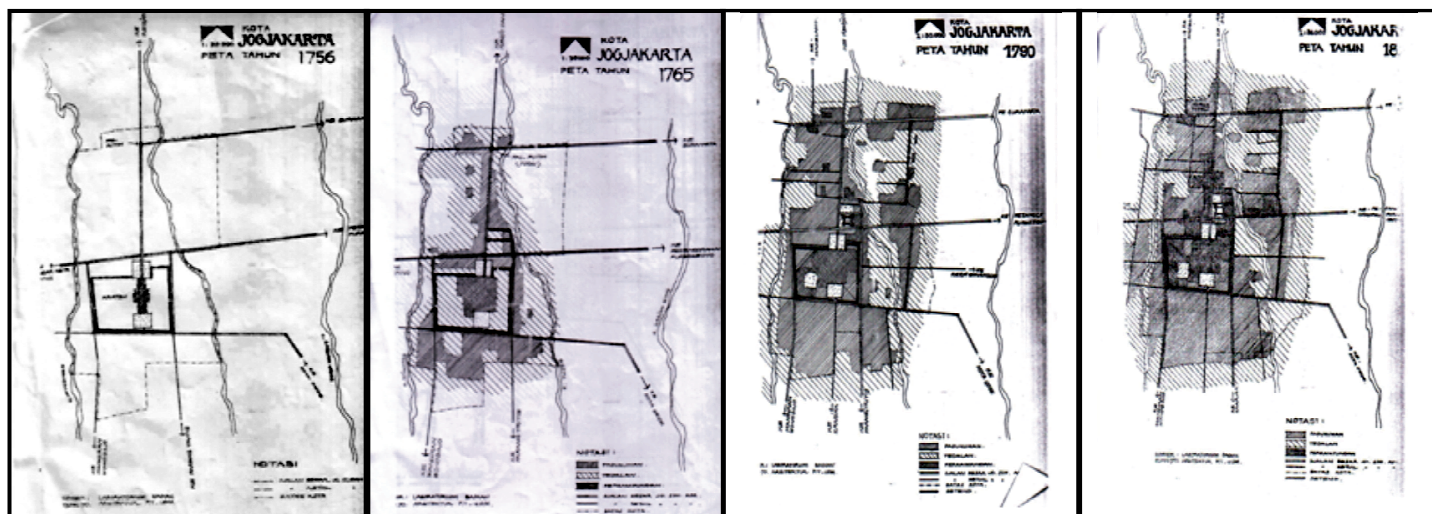

Gambar 1. Peta perkembangan kota Yogyakarta (Kawasan Jeron Benteng) tahun 1756 - 1800

Luas keseluruhan lahan Kawasan Jeron Benteng (Kecamatan Kraton) adalah $1.40 \mathrm{~km}^{2}$ dengan batas-batas wilayahnya adalah: Kecamatan Gondomanan (Sebelah Utara), Kecamatan Gondomanan / Kecamatan Mergangsan (Sebelah Timur), Kecamatan Mantrijeron (Sebelah Selatan), dan Kecamatan Mantrijeron/Kecamatan Ngampilan (Sebelah Barat).

Jumlah populasi penduduk Kecamatan Kraton adalah 29.468 jiwa dengan kepadatan penduduknya $20.049 \mathrm{jiw} / \mathrm{km}^{2}$ terbagi dalam 3 kelurahan (Panembahan, Patehan dan Kadipaten), 43 RW dan 175 RT. (lihat Gambar 2)

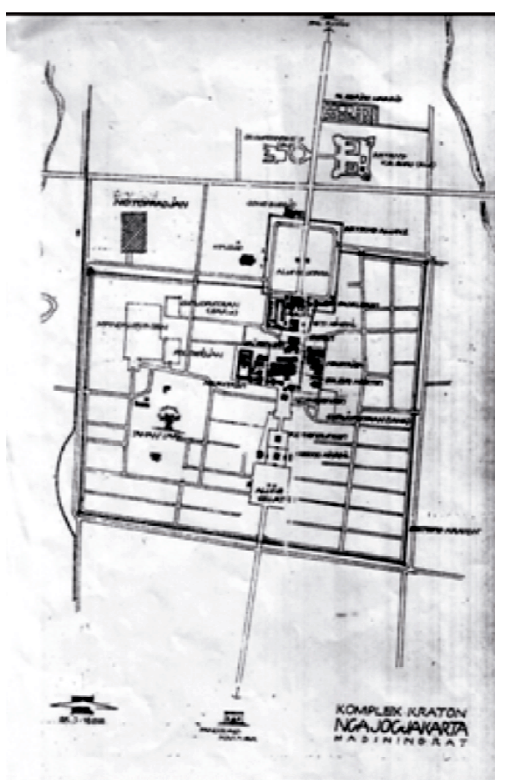

\section{Rumah Jawa}

Menurut Heinz Frick (1997:84), masyarakat Jawa menganggap bahwa rumah sebagai tempat tinggal diungkapkan sama dengan pribadi yang memilikinya. Sehingga menurut Suryanto Sastroatmojo (2006: 3132) penghidupan setiap insan lebih gumolong, genah, mapan, gumathok jikalau jelas pula pusat kediamannya, sebagai "puser" dari kegiatan kulturalnya. Dalam makna yang lebih tinggi lagi, sesungguhnya adalah representasi pemikiran dari pusat "lakon alam dan isinya", karena pada kenyataannya, dalem-dalem di Jawa sarat dengan piwulang suci.

Gambar 2. Denah Kecamatan Kraton tahun 1970 dan 2000 


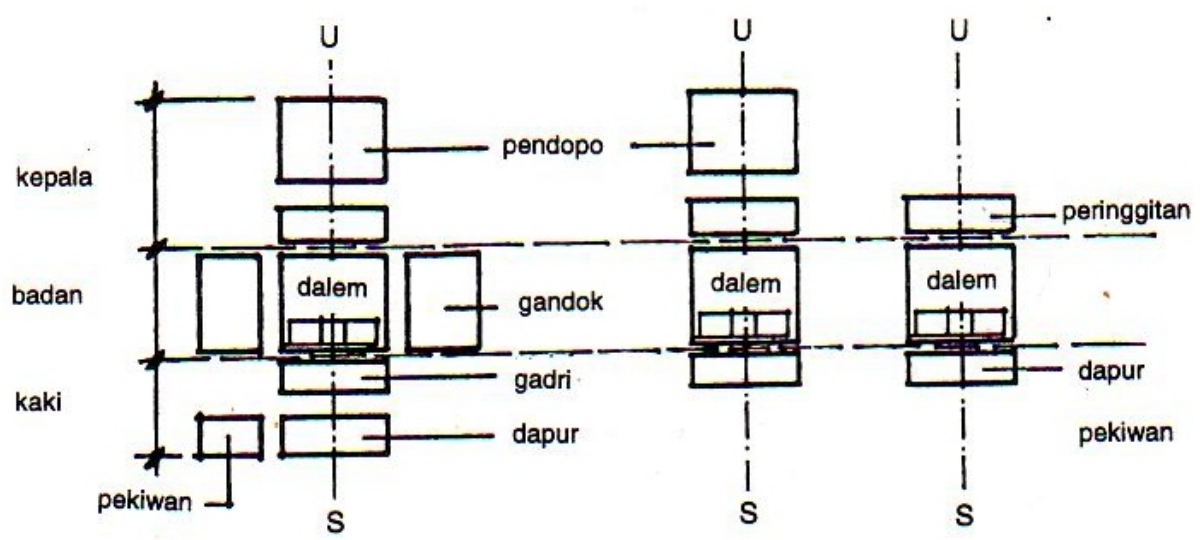

Gambar 3. Organisasi ruang pada rumah Jawa, Sumber: Heinz Frick (1997 : 87)

Pada rumah tinggal Jawa terdapat pembagian ruang-ruang berdasar gender. Misalnya bisa dilihat dari pendapat Heinz Frick (1997 : 86) bahwa Gandhok kiwa (wetan omah : timur rumah) untuk tidur kaum laki-laki dan gandhok tengen (kulon omah : barat rumah) untuk kaum perempuan. Sedangkan menurut Revianto Budi Santosa (2000 : 211215) Bagian depan sebuah rumah merupakan wilayah yang berorientasi keluar tempat prestise domestik dan keteraturan sosial ditampilkan dalam bentuk perbedaanperbedaan status dan formalitas. Menemui orang lain sering diasosiasikan dengan lakilaki, karena laki-laki dianggap (atau menganggap dirinya) sebagai pewakilan dari rumah yang harus berhadapan dengan dunia luar. Sebagai figur teladan dalam rumah tangga, dia wajib memelihara prestisnya. Sedangkan Bagian dalam dari rumah, yang diasosiasikan dengan perempuan, merupakan tempat kaum perempuan secara rutin melakukan tugas-tugas domestik mereka. Dalam ritus itu, perempuan mengemban kapasitas untuk menjaga kesejahteraan keluarga dan akumulasi kekuatan dalam rumah.

Di dalam perwujudannya dalam rumah tinggal, omah mburi atau rumah belakang (datem, senthong, gandhok, pawon dan kulah) merupakan domain wanita, sedang pendapa adalah domain laki-laki. Sementara pringgitan merupakan batas/ruang transisi antara kedua domain di atas. Jadi meskipun sering disebutkan bahwa semakin ke belakang, bagian rumah Jawa akan semakin privat, tetapi peran gender dalam konteks budaya Jawa dalam hal ini masih sangat berperan.

Tjahjono (1989:71) mengemukakan konsep tentang rumah tinggal Jawa adalah center and duality. Aktivitas yang berlangsung di dalam rumah terbagi menjadi aktivitas rutin (kegiatan sehari-hari) dan non-rutin (kegiatan ritual). Pembedaan gender di dalam ruangruang tidak berlaku tegas dalam aktivitas rutin yang melibatkan seluruh penghuni kecuali dapur (area wanita), sentong dan ruang tengah (area pria dan wanita), pojok selatanbarat (area wanita), pojok selatan-timur (area pria). Biasanya dalam beraktivitas rutin penghuni menghindari sentong tengah karena dipercaya pusat spiritual dari rumah dan kegiatan ritual, ruang yang menghubungkan tanah dengan udara melalui api.

\section{Tinjauan Tentang Gender}

Dalam buku "Analisis Gender dan Trasformasi Sosial", Mansour Fakih (1996) menjelaskan bahwa gender adalah perbedaan tingkah laku (behavioural differences) antar jenis kelamin yang dikonstruksikan oleh masyarakat (socially constructed). Gender secara konseptual berbeda dengan jenis kelamin (sex), dia lebih bermakna sebagai perilaku sosial, sehingga untuk memahami konsep gender harus dibedakan dengan pengertian jenis kelamin yang merupakan pemberian Tuhan (kodrat). 
Sementara gender sifatnya bukan kodrat Tuhan dan bukan biologis, melainkan diciptakan oleh masyarakat melalui proses sosial dan budaya yang panjang. Jadi, gender adalah : "suatu sifat yang melekat pada kaum laki-laki dan perempuan yang dikonstruksi secara sosial dan kultural". Sehingga identifikasinya berupa maskulinitas dan feminitas. Maskulin adalah karakteristk seksual yang bersifat kelaki-lakian dan feminim adalah karakteristik seksual yang bersifat kewanitaan.

Menurut Trisakti Handayani dan Sugiarti (2006:5), konsep gender adalah sifat yang melekat pada kaum laki-laki dan perempuan yang dibentuk oleh faktor-faktor sosial maupun budaya, sehingga lahir beberapa fungsi dan peran yang dibedakan menurut kedudukan, fungsi dan peran masing-masing dalam berbagai bidang kehidupan. Sementara, Ivan Illich (1983:6080) dalam kaitannya dengan pola ruang mengungkapkan bahwa pembedaan ruang atas dasar gender antar perempuan dan lakilaki merupakan pembedaan fungsi dan peralatan yang digunakan. Gender sendiri oleh Illich dipahami bukan sekedar perbedaan jenis kelamin, namun adanya suatu cara pandang yang melekat pada tiap manusia.

Dari segenap penelusuran tersebut, gender dapat dipahami sebagai suatu pemahaman masyarakat tertentu yang berada pada ranah konseptual (abstrak) sekaligus memiliki bahasa simbol yang berupa atribut-atribut seperti pola ruang, elemen arsitektur dan sebagainya. Pemahaman gender juga berada pada rentang yang luas, artinya pada suatu kelompok masyarakat tertentu bisa terjadi dikotomi pemahaman gender. Faktor penentu atau variabel pemahaman gender juga bermacam-macam, seperti usia, latar belakang sosial-ekonomi, budaya dan politik.

Menurut Christina S. Handayani, Ardhian Novianto dalam buku "Kuasa Wanita Jawa" (2004), laki-laki menempatkan diri pada posisi dominan, superordinat, sedangkan perempuan subordinat. Namun dalam posisinya yang subordinat itu, wanita Jawa pada kenyataannya juga membuktikan bahwa mampu memberi peran/andil yang penting dalam rumah tangga.
Kaitannya dalam sebuah rumah, rumah bagi perempuan merupakan tempat dimana ia dapat berperan lebih besar dan lebih bebas. Sepenuhnya dapat dikendalikannya termasuk dengan menata dan memelihara rumah. Keberhasilan memenuhi tugas tersebut akan dinilai (biasanya oleh tetangga, keluarga dan teman). Sulitnya untuk setiap perempuan karena dibelakangnya selalu ada citra "rumah ideal". Ideologi kedomestikan yang menjelaskan bagaimana benda-benda seharusnya ada dan terlihat, akan selalu mempengaruhi apa yang dia kerjakan; bahkan ketika ia bereaksi melawannya, biarpun selalu dibatasi oleh uang, ruang dan waktu. Padahal rumah biasanya dibangun oleh laki-laki yang apada umumnya lebih sering tanpa konsultasi dengan perempuan yang nantinya akan paling banyak berperan di rumah.

\section{BAHAN DAN METODE}

Jenis penelitian ini adalah penelitian deduktif kualitatif. Populasi pada penelitian ini adalah rumah tinggal-rumah tinggal di Kawasan Jeron Benteng (Kecamatan Kraton) Yogyakarta. Pengambilan sampel penelitian menggunakan teknik purposive sampling dan mencakup dua aspek (Sanapiah, 1990:5661) yaitu informan dan situasi sosial. Informan adalah subjek yang benar-benar mengetahui informasi yang dibutuhkan. Sementara situasi sosial merupakan subjek yang akan diamati dalam hal ini bisa berupa tempat (rona), lingkungan sosial, organisasi dan sebagainya. Situasi sosial yang dimaksudkan adalah ruang tamu, ruang keluarga dan dapur dengan segala kegiatan yang ada di dalamnya. Data yang telah dikumpul dianalisis dengan menggunakan analisis kualitatif. Dalam penelitian ini menggunakan teknik analisis data yang disebut dengan flow model of analysis, yaitu proses analisis yang saling menjalin masih tetap dilakukan pada waktu pengumpulan data sudah berakhir dan dilanjutkan sampai pada waktu penulisan laporan penelitian berakhir. Proses analisisnya terbagi menjadi tiga komponen utama, yaitu reduksi data, penyajian data dan verifikasi, penarikan kesimpulan (Sutopo, 2002:91). 


\section{HASIL DAN PEMBAHASAN}

Dari analisis tentang pergeseran gender diketahui bahwa Ruang tamu pada rumah tinggal masyarakat Jeron Beteng Kecamatan Kraton tidak seluruhnya berada di pendopo, hanya sebagian saja yang mempunyai ruang tamu di pendopo, itupun sudah mengalami renovasi guna memenuhi kebutuhan ruang dan keamanan. Dalam interior ruang tamu yang berada di pendopo yang domain laki-laki maupun di pringgitan yang merupakan batas transisi antara kedua domain di rumah tinggal masyarakat kawasan Jeron Benteng (Kecamatan Kraton) ada pergeseran gender dalam ruang tamu. Pergeseran ini dikarenakan tidak ditemukan dominasi gender antara kekuasaan laki-laki atau kekuasaan perempuan. Dilihat dari sudut peran gender antara bapak dan ibu mempunyai rasa kepemilikan yang sama terhadap ruang tamu, sama-sama memiliki status, terpengaruh adat, melaksanakan tugas domestik, dan sama-sama memiliki dominasi terhadap ruang tamu. Ruang tamu yang berada di wilayah depan sebagai perwujudan rasa 'hormat' bagi masyarakat Jawa tidak menjadi ruangnya laki-laki atau lebih dominan laki-laki saja, tapi kaum perempuan dan laki-laki mempunyai peran yang sama didalamnya.

Berdasarkan aspek tugas domestik, laki-laki dan perempuan sama-sama memiliki peran dalam ruang keluarga. Sedangkan komunikasi yang terjadi diruang keluarga antara laki-laki dan perempuan juga terjalin saling berkesinambungan. Namun dalam ruang keluarga masih tetap didominasi oleh kaum perempuan, hal ini nampak pada gagasan, wewenang dan kesempatan yang lebih pada kaum perempuan di ruang keluarga. Maka dapat disimpulkan bahwa terdapat pergeseran pada ruang keluarga, dimana pada penelitian sebelumnya ruang keluarga adalah domain perempuan, namun saat penelitian ini dilakukan pada masyarakat Jeron Beteng (Kecamatan Kraton) Yogyakarta, laki-laki sudah dapat mengakses.

Peran antara laki-laki dan perempuan di ruang lainnya, yaitu dapur, saat ini sudah memiliki persamaan dalam hal melakukan tugas domestik khususnya di ruang dapur dan terdapat keterbukaan dalam berpendapat serta komunikasi. Akan tetapi, walaupun dalam akses serta kedudukan antara laki-laki dan perempuan sama, tetap kaum perempuan yang lebih dominan di ruang dapur.

Faktor-faktor yang mempengaruhi pergeseran gender dalam ruang tamu lebih dikarenakan oleh realitas di masyarakat dan latar belakang penghuni, diantaranya adalah :

1. Modernisasi. Proses pergeseran sikap dan mentalitas untuk bisa hidup sesuai dengan kondisi di masa kini. Peran media sangat berpengaruh pada masuknya budaya barat pada masyarakat Jeron Beteng (Kecamatan Kraton) Yogyakarta.

2. Emansipasi wanita. Kegiatan yang dilakukan dalam mewujudkan persamaan hak antara wanita dan pria. Emansipasi wanita dalam keluarga dipengaruhi oleh beberapa hal :

a. Pernah tinggal di luar negri. Pernah tinggal di luar negri akan terpengaruh pada budaya setempat. Di negaranegara maju sudah mengakui persamaan hak dan kewajiban sebagai ujud gerakan emansipasi.

b. Usia. Usia mampu mempengaruhi banyak sedikitnya aktivitas yang bisa dikerjakan, termasuk masalah kesehata.

c. Pekerjaan. Pekerjaan sebagai penopang perekonomian dai dalam rumah tangga. Pekerjaan di luar rumah mempengaruhi banyak sedikitnya waktu luang dirumah untuk melakukan aktifitas di dalam rumah.

d. Pendidikan. Pendidikan meliputi pendidikan moral yang didapat di keluarga dan lingkungannya, dan pendidikan setinggi-tingginya dalam sebuah institusi formal.

3. Sikap menghormati. Sikap menghormati dalam keluarga sangat berpengaruh dalam kerukunan dan keharmonisan rumah tangga. Sikap menghormati bisa ditunjukkan dengan adanya interaksi dengan anggota keluarga untuk mencari kata sepakat. Keadaan hubungan yang tidak harmonis sangat berpengaruh di dalam pola kehidupan berumah tangga, sehingga sikap saling menghormati akan berkurang karena tiap individu lebih 
mementingkan pribadinya.

Sedangkan Faktor-faktor yang mepengaruhi pergeseran gender di ruang keluarga rumah tinggal kawasan Jeron Beteng (Kecamatan Kraton) Yogyakarta, diantaranya adalah:

1. Komunikasi. Komunikasi atau diskusi saling bertukar pendapat yang terjadi di ruang keluarga secara tidak langsung mendorong pada rasa kebersamaan dan keterbukaan.

2. Status perkawinan. Keadaan hubungan di dalam rumah tangga yang sudah tidak harmonis sangat berpengaruh dalam pola kehidupan di dalam rumah.

3. Usia. Usia mampu mempengaruhi banyak sedikitnya aktivitas yang bisa dikerjakan.

4. Pekerjaan. Pekerjaan sebagai penopang perekonomian di dalam rumah tangga. Pekerjaan di luar rumah mempengaruhi banyak sedikitnya waktu luang dirumah untuk melakukan aktifitas di dalam rumah.

5. Emansipasi. Kegiatan yang dilakukan dalam mewujudkan persamaan hak antara wanita dan pria. Gerakan emansipasi ini lebih banyak dilakukan oleh kaum wanita.

6. Modernisasi. Proses pergeseran sikap dan mentalitas untuk bisa hidup sesuai dengan kondisi di masa kini.

7. Pendidikan moral dan formal. Pendidikan adalah faktor yang menentukan karena pendidikan moral adalah ajaran mengenai perilaku, etika, akal budi yang baik yang ditanamkan sejak kecil oleh orang tua yang secara tidak langsung akan berpengaruh pada sikap dan perilaku ketika sudah dewasa dan menikah. Pendidikan formal didapat dari institusi yang mengajarkan berbagai macam pengetahuan umum dan mengenai kepribadian, bepengaruh pada pola pikir seseorang.

8. Pengaruh budaya asing. Sebagian orang yang pernah tinggal diluar negeri, maka secara tidak langsung akan berpengaruh pada pola kehidupannya.

Faktor-faktor yang mempengaruhi pergeseran gender pada ruang dapur di rumah tinggal Kawasan Jeron Benteng (Kecamatan Kraton) Yogyakarta, diantaranya adalah peran gender dan realitas yang sangat dipengaruhi oleh latar belakang penghuni diketahui dari statusnya dalam masyarakat dan keluarganya, diantaranya adalah:
1. Komunikasi. Kontak, hubungan, penyampaian dan penerimaan pesan serta kata sepakat merupakan hasil dari komunikasi antara laki-laki dan perempuan di ruang dapur.

2. Usia. Usia mampu mempengaruhi banyak sedikitnya aktivitas yang dapat dikerjakan. Dalam kenyataannya di Kawasan Jeron Benteng, karena faktor usia (tua) maka laki-laki (bapak) mengakses dapur.

3. Pekerjaan. Pekerjaan sebagai penopang perekonomian di dalam rumah tangga. Karena bidang usaha wiraswasta dan pensiunan, maka laki-laki dapat sering mengakses dapur.

4. Emansipasi. Kegiatan yang dilakukan dalam mewujudkan persamaan hak antara wanita dan pria. Gerakan emansipasi ini lebih banyak dilakukan oleh kaum wanita.

5. Modernisasi. Proses pergeseran sikap dan mentalitas untuk bisa hidup sesuai dengan kondisi di masa kini.

6. Pendidikan moral dan formal. Pendidikan adalah faktor yang menentukan karena pendidikan moral adalah ajaran mengenai perilaku, etika, akal budi yang baik yang ditanamkan sejak kecil oleh orang tua yang secara tidak langsung akan berpengaruh pada sikap dan perilaku ketika sudah dewasa dan menikah. Pendidikan formal didapat dari institusi yang mengajarkan berbagai macam pengetahuan umum dan mengenai kepribadian, bepengaruh pada pola pikir seseorang

\section{DAFTAR ISTILAH :}

Dalem: Rumah inti pada rumah Jawa tradisional. Terletak di belakang pendopo dan pringgitan. Bagian ini terdiri atas tiga area, yaitu tiga kamar yang disebut senthong tengah, senthong kiwo, senthong tengen.

Gadri: Serambi (ruang makan) yang terletak di belakang dalem agung

Gandhok: Bangunan kecil memanjang yang terdapat di sekitar omah njero. Kata gandhok dalam bahasa jawa berarti pasangan atau rekatan yang ditambahkan. Ruang ini merupakan bangunan tambahan yang mengitari sisi samping dam belakang bangunan inti.

Kulah: Kamar mandi

Pawon: Dapur 
Pendhopo: Ruangan yang berada pada bagian terdepan dari keseluruhan bangunan.

Piwulang: Ajaran

Pringgitan: merupakan lorong penghubung antara pendopo dengan omah njero. Bagian pringgitan ini sering difungsikan sebagai tempat pertunjukan wayang kulit

Senthong Kiwo: Ruang tidur tuan rumah; terletak bagian belakang dalem agung sebelah kanan.

Senthong tengah: Ruang ini merupakan ruang yang sakral yang sering menjadi tempat pelaksanaan upacara atau ritual keluarga. Tempat ini juga menjadi tempat penyimpanan benda-benda pusaka keluarga penghuni rumah.

Senthong tengen: Ruang pengantin lengkap dengan pelaminan selama 35 hari sesudah perkawinan; terletak di bagian belakang dalem agung sebelah kiri.

Regol: Bangunan "regol" (gapura), asalnya dari kata "rigol" juga "parigolan", dimaksudkan sebagai pengetrapan tatakrama/tata-susila antara muda kepada tua, antara kecil kepada yang besar. "Parigolan" adalah batas pemberhentian dari kendaraan, atau membuka/menutup payung, topi, atau turunnya dari pendapa ke "regol". Hormat kepada tamu lebih tua atau tinggi derajat / pangkatnya. Turunnya dari tempat atau kendaraan itu diumpamakan "rigol" (rigol = jatuh).

Candrasangkala: Angka tahun (hari, bulan) yang dirahasiakan dalam kata-kata atau gambar tertentu pada kalimat atau semboyan..

\section{DAFTAR PUSTAKA}

Fakih, Mansour. 1996. Analisis Gender dan Trasformasi Sosial. YOGYAKARTA: Pustaka Pelajar.

Frick, Heinz. 1997. Pola Struktural dan Teknik Bangunan di Indonesia. YOGYAKARTA: Kanisius.

Handayani, Christina S., \& Novianto, Ardhian. 2004. Kuasa Wanita Jawa. YOGYAKARTA: LKIS Pelangi Aksara.
Handayani, Trisakti \& Sugiarti. 2006. Konsep dan Teknik Penelitian Gender. MALANG: UMM Press.

Illich, Ivan. 1993. Gender. LONDON: Marion Boyars Publishers Ltd.

Sanapiah, Faisal. 1990. Penelitian Kualitatif: Dasar-Dasar dan Aplikasi. MALANG: Yayasan Asih, Asah, Asuh.

Santosa, Revianto Budi. 2000. Omah: Membaca Makna Rumah Jawa. YOGYAKARTA: Yayasan Bentang Budaya.

Sastroatmodjo, Suryanto. 2006. Citra Diri Orang Jawa. YOGYAKARTA: Narasi

Soekanto, Soerjono. 1990. Sosiologi, Suatu Pengantar. JAKARTA: PT Raja Grafindo Persada

Sutopo, H.B. 2002. Metodologi Penelitian Kualitatif. SURAKARTA: Sebelas Maret University Press.

Tjahjono, Gunawan. 1989. Cosmos, Center and Duality in Javanese Architectural Traditions: The Symbolic Dimensions of House Shapes in Kotagede and Surroundings. (Disertasi). BERKELEY: Doctor of Philosophy bidang Arsitektur University of California. 
LUNTAS NG | VOL.2 | EDISI 2 | 2008 ISSN 1978-0702 